\title{
Perbandingan Konsep Belajar, Strategi Pembelajaran dan Peran Guru (Perspektif Behaviorisme dan Konstruktivisme)
}

\author{
ZALYANA \\ Fakultas Tarbiyah dan Keguruan Universitas Islam Negeri Sultan Syarif Kasim Riau \\ Jl. H.R. Soebrantas no. 155 km. 18 Pekanbaru. Email: zalyanaau@ymail.com
}

\begin{abstract}
Abstrak: Teori pembelajaran dapat dimaknai juga sebagai cara pandang seseorang tentang belajar, mengapa, dan bagaimana proses belajar itu terjadi. Terdapat berbagai pandangan atau teori yang menjelaskan bagaimana belajar dan pembelajaran itu terjadi.Seperti teori Behaviorisme dan Konstructivisme. Kedua teori ini bertolak belakang di dalam memandang konsep, dan strategi belajar, serta peran guru di dalamnya. Oleh karena itu tulisan ini akan berusaha untuk membandingkan ketiga konsep di atas dengan tujuan ingin mengetahui pandangan teori Behaviorisme dan Konstruktivisme tentang belajar, strategi dan peran guru. Untuk tujuan di atas penulis menggunakan metode induktif Komparasi yang dikemukan oleh George ZF. Bereday.
\end{abstract}

Keyword: Behaviorisme, Konstruktivisme, Komparasi, belajar, strategi.

\section{PENDAHULUAN}

Kajian mengenai strategi pembelajaran secara sistematis relatif baru. Sampai akhir abad 19, belajar dianggap masalah dalam dunia keilmuan. Dengan menggunakan teknologi yang digunakan oleh ilmu fisika, para peneliti mencoba menghubungkan pengalaman untuk memahami bagaimana manusia dan hewan belajar. Pengalamanpengalaman tersebut melahirkan suatu teori yang dapat diterapkan dalam pembelajaran bagi manusia.

Teori adalah interpretasi sistematis atas sebuah bidang pengetahuan. Sebuah teori pembelajaran mempunyai fungsi pertama: teori pembelajaran menggambarkan sudut pandang peneliti mengenai aspek-aspek pembelajaran yang paling bernilai untuk dipelajari, variabel-variabel independen yang harus dimanipulasi dan variabel dependen yang harus dikaji, teknik-teknik penelitian yang hendak digunakan dan bahasa apa yang harus digunakan untuk mendeskripsikan temuan-temuannya. Dengan demikian teori berfungsi sebagai pertama: petunjuk dan sumber stimulasi bagi penelitian dan pemikiran ilmiah. Kedua: teori pembelajaran berupaya untuk meringkas sejumlah pengetahuan mengenai hukum-hukum pembelajaran ke dalam ruang yang cukup kecil. Ketiga: teori pembelajaran 
secara kreatif berupaya menjelaskan apa itu pembelajaran dan mengapa pembelajaran berlangsung seperti adanya.Hukum-hukum menunjukkan "bagaimana" pembelajaran terjadi, "mengapa" pembelajaran terjadi (Winfred, 2010: 27-28).

Jadi, teori pembelajaran berusaha menghasilkan pemahaman pokok tersebut yang merupakan salah satu tujuan ilmu pengetahuan dan juga bentuk-bentuk kegiatan ilmiah lainnya. Teori merepresentasikan upaya terbaik untuk memastikan struktur apa yang melandasi dunia tempat kita hidup.

Dari pemahaman tentang makna teori di atas dan bila dikaitkan juga dengan pembelajar, teori pembelajaran dapat dimaknai juga sebagai cara pandang seseorang tentang belajar, mengapa, dan bagaimana proses belajar itu terjadi.

Berangkat dari kesimpulan di atas, terdapat berbagai pandangan atau teori yang menjelaskan bagaimana belajar dan pembelajaran itu terjadi. Seperti teori Behaviorisme, Kognitivisme, Konstructivisme, dan Humanisme.

Pandangan Behaviorisme yang menganggap belajar adalah perubahahan perilaku yang tampak, dan selalu dapat terukur,hubungan stimulus- respon, selalu dipertentangkan dengan pandangan Konstruktivisme di mana siswa membangun pengetahuannya melalui pengalaman, sehingga proses belajar sangat dinamis dan berpusat pada siswa.

Dalam tulisan ini penulis mencoba memperbandingkan kedua teori tersebut. Dipilihnya kedua teori paling tidak sudah memenuhi syarat kesebandingan (komparability) yaitu dari segi objeknya teori tersebut memiliki kesamaan objek yaitu mengkaji perilaku individu dalam belajar.

Untuk tujuan tersebut penulis menggunakan metode komparasi yang dikemukan oleh George ZF. Bereday, seorang Profesor di bidang Pendidikan Komparatif dari Columbia University Amerika Serikat yaitu metode induktif Komparasi dengan langkah-langkah prosedural sebagai berikut (Rohman, 2013: 106-108): (a) Penggalian Data, yaitu dengan cara membaca berbagai literatur yang membahas tentang konsep belajar dari kedua teori tersebut; (b) Deskripsi Data, yaitu menyaji semua data yang diperoleh dalam bentuk teks atau uraian; (c) Interpretasi, setelah data disajikan selanjutkan diinterpretasikan dengan cara menganalisis data yang telah tersaji; (d) Komparasi Awal, yaitu menentukan hal-hal apa saja yang harus dikomparasikan, dalam tulisan ini penulis akan mengkomparasikan tentang konsep belajar, strategi dan peran guru; (e) Perumusan Hipotesis yaitu menemukan hasil komparasi yang masih bersifat sementara. Hipotesis berisikan tentang pernyataan perbandingan dari sisi persamaan dan perbedaan kedua teori tersebut; (f) Komparasi final, yaitu menganalisa secara cermat dan mendalam sehingga menemukan sisi persamaan dan perbedaan; dan (g) Kesimpulan, menetapkan perbedaan dan persamaan serta menetapkan rekomendasi.

\section{PEMBAHASAN}

Belajar secara sederhana didefinisikan sebagai aktivitas yang dilakukan oleh individu secara sadar untuk mendapatkan sejumlah kesan dari apa yang telah dipelajari dan sebagai hasil dari interaksinya dengan lingkungan sekitarnya. 
Belajar juga merupakan proses manusia untuk mencapai berbagai macam kompetensi, keterampilan, dan sikap. Belajar dimulai sejak manusia lahir sampai akhir hayatnya, sebagaimana yang dijelaskan Rasulullah Saw yang artinya," Tuntutlah ilmu sejak dari ayunan sampai liang lahat" HR.

Secara bahasa belajar memiliki arti " berusaha memperoleh kepandaian atau ilmu “. Hilgrad dan Bower juga mengartikan belajar adalah memperoleh pengetahuan atau menguasai pengetahuan, melalui pengalaman, mengingat, menguasai pengalaman, dan mendapatkan informasi atau menemukan. Secara istilah, Cronbach menyatakan bahwa belajar yang terbaik adalah dengan pengalaman. Dengan pengalaman pelajar menggunakan seluruh panca inderanya.

Slameto, (1999), menyatakan bahwa belajar merupakan suatu usaha yang dilakukan oleh individu untuk memperoleh suatu perubahan tingkah laku yang baru secara keseluruhan, sebagai hasil dari pengalaman individu sendiri dalam interaksi dengan lingkungannya (Slameto, 1991: 23).

Surya (1997) menjelaskan pula bahwa belajar ialah suatu proses yang dilakukan individu untuk memperoleh suatu perubahan tingkah laku yang baru secara keseluruhan sebagai hasil dari pengalaman individu sendiri dalam interaksi dengan lingkungannya .

Islam sebagai agama Rahmatan liAl 'amin sangat mewajibkan umatnya untuk selalu belajar. Aktifitas belajar sangat terkait dengan proses pencarian ilmu. Islam sangat menekankan pentingnya ilmu. Al-Quran dan Hadis mengajak kaum muslimin untuk mencari dan mendapatkan ilmu dan kearifan, serta menempatkan orang- orang yang berilmu pada derjat yang tinggi.

Dari beberapa difinisi di atas dapat disimpulkan adanya beberapa ciri belajar antara lain: (a) Belajar adalah suatu proses atau tahapan artinya hasil yang didapat tidak serta merta diperoleh tetapi melalui tahapan; (b) Belajar ditandai adanya perubahan tingkah laku . Ini berarti bahwa hasil belajar hanya dapat diamati dari tingkah laku, yaitu adanya perubahan tingkah laku, dari tidak tahu menjadi tahu, dari tidak trampil menjadi trampil; (c) Perubahan prilaku relatif permanent. Ini berarti perubahan tingkah laku yang terjadi karena belajar untuk waktu tertentu akan tetap tidak berubah-ubah. Tetapi perubahan tingkah laku tersebut tidak akan terpancang seumur hidup; (d) Perubahan bersifat fungsional artinya, perubahan yang telah diperoleh sebagai hasil pembelajaran memberikan manfaat bagi individu yang belajar. Misalnya kecakapan dalam bebbicara bahasa Arab memberikan manfaat untuk hal-hal yang lebih luas lagi; (e) Perubahan bersifat positif, artinya terjadi adanya perubahan tambahan dalam diri individu. Perubahan yang diperoleh senantiasa bertambah sehingga berbeda dengan keadaan yang sebelumnya. Orang yang belajar akan merasakan sesuatu yang lebih banyak, sesuatu yang lebih baik, dari keadaan yang sebelumnya. Orang yang telah belajar akan merasakan ada sesuatu yang lebih banyak, sesuatu yang lebih baik, sesuatu yang lebih luas dalam dirinya. Misalnya pengetahuan menjadi lebih banyak, prestasinya meningkat, kecakapannya menjadi lebih baik; (f) Perubahan bersifat aktif artinya perubahan itu tidak teradi dengan sendirinya, akan tetapi melalui aktifitas individu; (g) Perubahan tingkah laku tidak harus segera dapat diamati pada 
saat proses belajar sedang berlangsung, perubahan tersebut bersifat potensial; (h) Perubahan tingkah laku merupakan hasil latihan dan pengalaman; (i) Pengalaman atau latihan itu dapat memberi penguatan.Sesuatu yang memperkuat itu akan memberikan semangat atau dorongan untuk mengubah tingkah laku; dan (j) Belajar adalah dalam rangka memperoleh ilmu, dan orang yang berilmu akan memperoleh derajat yang tinggi di sisi allah Swt.

\section{Teori Behaviorisme Konsep Belajar}

Menurut Behaviorisme, belajar adalah perubahan tingkah laku akibat dari adanya interaksi antara stimulus dan respon. Dengan kata lain, belajar merupakan bentuk perubahan yang dialami dalam hal kemampuannya untuk bertingkah laku dengan cara baru sebagai interaksi antara stimulus dan respon. Seseorang dianggap telah belajar sesuatu jika ia dapat menunjukkan perubahan tingkah lakunya .Sebagai contoh, anak belum dapat berhitung perkalian. Walaupun ia sudah berusaha giat, dan gurunya pun sudah mengajarkannya dengan tekun, namun jika anak tersebut belum dapat mempraktekkan perhitungan perkalian, maka ia belum dianggap belajar. Karena ia belum dapat menunjukkan perubahan perilaku sebagai hasil belajar (Budiningsih, 2005: 15).

Menurut teori ini yang terpenting adalah input (masukan) yang berupa stimulus dan out put (keluaran) yang berupa respon. Dalam contoh di atas, stimulus adalah apa saja yang diberikan guru kepada siswanya, misalnya daftar perkalian, alat peraga, pedoman kerja, atau cara-cara tertentu, untuk membantu belajar siswa, sedangkan respon adalah reaksi atau atau tanggapan siswa terhadap stimulus yang diberikan oleh guru. Menurut teori behavioristik apa yang terjadi antara stimulus dan respon dianggap tidak penting diperhatikan karena tidak dapat diamati dan tidak dapat diukur. Yang dapat diamati adalah stimulus dan respon. Oleh sebab itu, apa saja yang diberikan guru (stimulus) dan apa saja yang dihasilkan siswa (respon), semuanya harus dapat diukur. Teori ini mengutamakan pengukuran, sebab pengukuran merupakan suatu hal yang penting untuk melihat terjadi tidaknya perubahan tingkah laku tersebut.

Faktor lain yang juga dianggap penting oleh aliran behavioristik adalah faktor penguatan (reinforcement). Penguatan adalah apa saja yang dapat memperkuat timbulnya respon. Bila penguatan ditambahkan, maka respon akan semakin kuat. Begitu pula bila penguatan dikurangi responpun akan tetap dikuatkan. Misalnya, ketika peserta didik diberi tugas oleh gurunya, ketika tugasnya di tambahkan maka ia akan semakin giat belajarnya. Maka penambahan tugas tersebut merupakan penguatan positif dalam belajar. Bila tugas-tugas dikurangi dan pengurangi justru meningkatkan aktivitas belajarnya, maka pengurangan tugas merupakan penguatan negatif dalam belajar. Jadi penguatan merupakan suatu bentuk stimulus yang penting diberikan atau dikurangi untuk memungkinkan terjadinya respon.

Berdasarkan hasil eksperimen yang dilakukan oleh Pavlov dengan meneliti seekor anjing ia menyimpulkan bahwa hasil eksperimennya juga dapat diterapkan pada manusia untuk belajar. Implikasi hasil eksperimen tersebut pada belajar manusia adalah: (a) Belajar adalah membentuk asosiasi antara stimulus-respon secara selektif; (b) Proses belajar akan berlangsung apabila diberi stimulus bersyarat; (c) Prinsip 
belajar pada dasarnya merupakan untaian stimulus-respon;

Menyangkal adanya kemampuan bawaan; dan (e) Adanya clasical conditioning.

Eksperimen Pavlov tersebut kemudian dikembangkan oleh pengikutnya yaitu BF. Skinner (1933) dan hasilnya dipublikasikan dengan judul Behavior of Organism. Menurut Skinner, apabila dalam belajar diberikan penguatan, maka akan dapat meningkatkan perilaku belajar.

Menurut Gutrie, peningkatan hasil belajar secara berangsur-angsur yang dicapai oleh siswa bukanlah hasil dari pelbagai respons kompleks terhadap stimulus-stimulus sebagaimana yang diyakini oleh behavioris lainnya, melainkan karena kedekatan asosiasi antara stimulus dan respon.

Dari uraian di atas dapat disimpulkan bahwa dalam hal belajar teori Behaviorisme memiliki ciri-ciri bahwa: (a) Belajar adalah perubahan perilaku; (b) Perilaku tersebut harus selalu tampak; (c) Perilaku harus dapat diukur; (d) Mengakui pentingnya masukan atau input yang berupa stimulus dan keluaran atau output yang berupa respon; (e) Fungsi mind atau fikiran adalah untuk menciplak struktur pengetahuan yang sudah ada melalui proses berfikir yang dapat dianalisis dan dipilah; (f) Pembiasaan dan latihan menjadi esensial dalam belajar; (g) Apa yang terjadi antara stimulus dan respon dianggap tidak penting diperhatikan karena tidak dapat diamati; (h) Yang dapat diamati dan diukur hanyalah stimulus respons; (i) Kegagalan atau ketidakmampuan dalam penamba-han pengetahuan dikategorikan sebagai kegagalan yang perlu dihukum; dan (j) Mementingkan penguatan/ reinforcement.

\section{Strategi Pembelajaran}

Strategi pembelajaran dalam hal ini dimaknai sebagai cara siswa belajar dan cara guru mengajar perspektif Behaviorisme.

Menurut Behaviorisme, belajar adalah perubahan tingkah laku akibat dari adanya interaksi antara stimulus dan respon. Dengan kata lain, belajar merupakan bentuk perubahan yang dialami dalam hal kemampuannya untuk bertingkah laku dengan cara baru sebagai interaksi antara stimulus dan respon. Seseorang dianggap telah belajar sesuatu jika ia dapat menunjukkan perubahan tingkah lakunya.

Pandangan di atas berimplikasi terhadap aktivitas siswa, yang mana siswa dikondisikan sebagai individu yang pasif, siap menerima stimulus dari guru atau dari manapun juga. Karena itu dalam belajar siswa banyak mendengar, mencatat, dan mengulangulang stimulus yang diberikan oleh guru. Dalam pandangan Behaviorisme, guru sangat berperan memberikan stimulus kepada siswa. Agar siswa dapat merespon dengan baik, maka siswa dapat melakukan sebagai berikut: (a) Membiasakan perilaku yang dikondisikan; (b) Mengulang-ulang sehingga menjadi kebiasaan; (c) Trial and Error; dan (d) Mendengar dan mencatat stimulus dari guru.

\section{Peran Guru}

Penerapan teori behaviroristik yang salah dalam suatu situasi pembelajaran juga mengakibatkan terjadinya proses pembelajaran yang sangat tidak menyenangkan bagi siswa . siswa diposisikan sebagai individu yang pasif, menerima berbagai stimulus dari guru. Sedangkan guru diposisikan sebagai individu aktif. Karena itu dalam pandangan Behaviorisme, guru 
berperan sebagai: (a) Sosok yang menentukan dimana isyarat dapat memancing respon siswa; (b) Pengajar, yaitu menyampaikan berbagai stimulus; (c) Pengatur, yaitu mengatur promting (bimbingan )untuk dipasangkan dengan stimulus; (d) Pengatur kondisi lingkungan sehingga siswa dapat merespon dengan benar dan siswa dapat menerima reinfoecement; (e) Model yang selalu mencontohkan perilaku kepada siswa; dan (f) Pemberi instruksi singkat yang diikuti contohcontoh baik dilakukan sendiri maupun melalui simulasi.

Teori behavioristik ini sebagaimana yang dikemukakan Syah memiliki kekurangan diantaranya (Syah, 2004: 110). Memandang belajar sebagai kegiatan yang dialami langsung, padahal belajar adalah kegiatan yang ada dalam sistem syaraf manusia yang tidak terlihat kecuali melalui gejalanya.

Proses belajar dipandang bersifat otomatis-mekanis sehingga terkesan seperti mesin atau robot, padahal manusia mempunyai kemampuan self regulation dan self control yang bersifat kognitif. Sehingga, dengan kemampuan ini, manusia bisa menolak kebiasaan yang tidak sesuai dengan dirinya.

Proses belajar manusia yang dianalogikan dengan hewan sangat sulit diterima, mengingat ada perbedaan yang cukup mencolok antara hewan dan manusia.

Di tengah derasnya kritik terhadap Behaviorisme, paling tidak terdapat beberapa kelebihan bahwa Metode behavioristik ini sangat cocok untuk perolehan kemampaun yang membuthkan praktek dan pembiasaan yang mengandung unsur-unsur seperti kecepatan, spontanitas, kelenturan, reflek, daya tahan dan sebagainya, contohnya: percakapan bahasa asing, mengetik, menari, menggunakan komputer, berenang, olahraga dan sebagainya.

Teori ini juga cocok diterapkan untuk melatih anak-anak yang masih membutuhkan dominansi peran orang dewasa, suka mengulangi dan harus dibiasakan, suka meniru dan senang dengan bentuk-bentuk penghargaan langsung seperti diberi hadiah atau pujian.

\section{Teori Konstruktivisme Konsep Belajar}

Konstruktivisme berasal dari filsafat yang digagas oleh Mark Baldwin dan selanjutnya dikembangkan oleh jean Piaget. Aliran filsafat Konstruktivisme berangkat dari pemikiran epistemology Giambabstista Vico yaitu "Tuhan adalah pencipta alam semesta dan manusia adalah tuan dari ciptaannya (Budiningsih, 2005: 23).

Vico dalam Wina sanjaya menyebutkan, pengetahuan itu tidak lepas dari orang (subjek) yang tahu. Pengetahuan merupakan struktur konsep dari subjek yang mengamati (Sanjaya, 2005: 118).

Hakikat pengetahuan dalam filsafat Konstruktif mempengaruhi konsep tentang belajar, bahwa belajar bukanlah sekedar menghafal, tetapi proses mmengkonstruksi pengetahuan melalui pengalaman. Pengetahuan bukanlah semata hasil "pemberian" dari orang lain seperti guru, akan tetapi hasil dari dari proses mengkonstruksi yang dilakukan setiap individu. Pengetahuan hasil dari pemberitahuan tidak akan menjadi pengetahuan yang bermakana.

Lebih lanjut, Piaget mengemukakan bahwa setiap anak sejak kecil sudah memiliki struktur kognitif yang kemudian dinamakan skema. Skema terbentuk karena pengalaman. Sebagai contoh; seorang 
anak bermain dengan kucing dan kelinci yang sama-sama berbulu putih. Karena keseringannya bermain, ia dapat menangkap perbedaan keduanya, yaitu, kucing berkaki empat, sedangkan kelinci berkaki dua. Semakin dewasa anak, maka semakin sempurnalah skema yang dimilikinya. Proses penyempurnaan skema dilakukan melalui proses mengubah skema yang ada hingga terbentuk skema baru. Asimilasi maupun akomodasi terbentuk berkat pengalaman siswa (Sanjaya, 2005: 111).

Untuk lebih jelasnya contoh asimilasi dan akomodasi dapat disimak contoh berikut; Pada suatu hari anak merasa sakit karena terpecik api, maka berdasarkan pengalamannya terbentuk skema pada struktur kognitif anak tentang "api". Adalah sesuatu yang membahayakan oleh karena itu harus dihindari.Dengan demikian, ketika anak melihat api scara reflek akan menghindari. Semakin anak dewasa, pengalaman anak tentang api bertambah pula ketika anak melihat ibunya memasak pakai api. Ketika bapak merokok menggunakan api, maka skema yang terbentuk itu disempurnakan bahwa api bukanlah harus dihindari, tetapi dapat dimanfaatkan, akan tetapi sangat dinutuhkan untuk kehidupan manusia. Proses penyempurnaan skema itu dinamakan akomodasi (Sanjaya, 2005: 112-113).

Sebelum anak mampu menyusun skema baru, ia akan dihadapkan pada posisi ketidakseimbangan (disequilibrium) yang akan mengganggu psikologis anak. Manakala anak berhasil membentuk skema baru, anak akan kembali pada posisi seimbang (equilibrium), dan selanjutnya memperoleh pengalaman baru.

Jadi, apa yang dijelaskan Piaget di atas dan juga penganut konstruktivistik, bahwa pengetahuan dibuat secara aktif oleh siswa, atau seseorang yang berfikir. Seseorang tidak akan meyerap pengetahuan dengan pasif. Untuk membangun suatu pengetahuan baru, peserta didik akan menyesuaikan informasi baru dengan pengetahuan dan pengalaman yang telah dimilikinya melalui berinteraksi sosial dengan peserta didik lainnya dan dengan gurunya.

Esensi teori konstruktivisme adalah bahwa siswa menemukan dan mentransformasikan suatu informasi yang kompleks ke situasi lain dan apabila dikehendaki informasi itu menjadi milik mereka sendiri, dengan dasar ini pembelajaran harus dikemas menjadi proses mengkonstruksi bukan menerima pengetahuan semata.

Dapat dijelaskan bahwa dalam Konstructivisme terdapat beberapa ciriciri, yaitu: (a) Siswa membangun pemahamannya sendiri dari hasil mereka belajar bukan karena disampaikan pada mereka; Pelajaran baru sangat tergantung dengan pelajaran sebelumnya; (c) Belajar dapat ditingkatkan dengan interaksi sosial; (d) Penugasanpenugasan dalam belajar dapat meningkatkan kebermaknaan proses pembelajaran; dan (e) Siswa membangun interpretasi personal terhadap dunia luar berdasarkan pengalaman individual dan interaksi.

\section{Strategi Pembelajaran}

Teori Konstruktif menyatakan bahwa siswa harus menemukan sendiri dan mentrasformasikan informasi kompleks, mengecek informasi baru dengan aturan-aturan lama dan merevisinya apabila aturan-aturan itu tidak lagi sesuai. Dalam teori ini guru tidak hanya sekedar memberikan pengetahuan kepada siswa. Siswa harus 
membangun sendiri di dalam benaknya, dengan arti kata siswa harus aktif. Sementara guru berperan sebagai fasilitator yang membantu siswa belajar. Sebagai fasilitator guru dituntut menggunakan strategi-strategi belajar aktif. Dalam dunia pendidikan strategi diartikan sebagai perencanaan yang berisi tentang rangkaian kegiatan yang didesain untuk mencapai tujuan pendidikan tertentu (Sanjaya, 2010: 126).

Strategi pembelajaran aktif dimaknai dengan serangkaian upaya yang dilakukan oleh pengajar bahasa Arab untuk membuat proses pembelajaran berjalan sesuai dengan konsep yang sebenarya. Sebuah proses pembelajajaran pada dasarnya adalah harus mampu menciptakan kondisi yang memungkinkan para siswanya belajar. Dalam pembelajaran aktif, peranan pengajar bukanlah satusatunya nara sumber dan yang paling banyak menggunakan waktunya di kelas. Pengajar lebih banyak berperan sebagai fasilitator yang bertugas memandu, mendampingi dan memberikan pengarahan kepada para siswa agar mereka dapat mengarah pada pencapaian tujuan belajar.

Kaitannya dengan konstruktivisme di atas, bahwa dalam pembelajaran guru/dosen dapat pula menggunakan strategi-strategi pembelajaran aktif sebagaimana yang ada, karena strategi-strategi tersebut dinilai mampu membuat siswa belajar secara efektif dengan menggunakan pengalaman, berfikir, bekerja dalam kelompok, menggunakan pengetahuan yang ada seperti yang tergambar dalam teori konstruktivisme. Pembelajaran aktif memiliki beberapa kelebihan diantaranya; belajar menjadi proses yang menyenangkan (learning is fun), karena siswa terlibat aktif dalam proses itu. Pengetahuan yang mereka peroleh, mereka konstruksi sendiri melalui pengalaman belajar bukan melalui transfer dari guru, dengan ddengan demikian pembelajaran menjadi lebih bermakna.

Selain itu seperti yang dijelaskan oleh Hisyam Zaini dalam bukunya, bahwa pembelajaran aktif sesuai dengan realita bahwa siswa/ mahasiswa memiliki berbagai gaya belajar atau learning style (meaningfull) (Zaini, 2010: 18).

\section{Peran Guru}

Menurut pandangan konstruktivisme, seorang pengajar atau guru atau dosen berperan sebagai mediator dan fasilitator yang membantu proses belajar siswa dan mahasiswa agar berjalan dengan baik. Tekanan ada pada siswa atau mahasiswa yang sedang belajar bukan pada disiplin ataupun guru yang mengajar. Fungsi mediator dan fasilitator dapat terlihat dalam tugas seperti: pertama, menyediakan pengalaman belajar yang memungkinkan siswa dan mahasiswa bertanggungjawab membuat rancangan, proses, dan penelitian. Karena itu memberi kuliah atau ceramah bukanlah satu-satunya tugas guru atau seorang dosen. Kedua, Menyediakan atau memberikan kegiatan-kegiatan yang merangsang keingintahuan siswa dan membantu mereka untuk mengekspresikan gagasannya dan mengkomunikasikan gagasan ilmiah mereka. Ketiga, Menyediakan sarana yang menstimulus mereka berfikir secara produktif. Menyediakan kesempatan dan pengalaman yang paling mendukung proses belajar siswa. Guru/dosen harus memotivasi siswa/mahasiswa. Guru harus menyediakan pengalaman yang mengandung konflik yang memungkinkan siswa/ mahasiswa 
berfikir, berargumentasi demi mencari solusi. Keempat, Memonitor, mengevaluasi, dan menunjukkan apakah pemikiran siswa atau mahasiswa jalan atau tidak. Guru menunjukkan dan mempertanyakan apakah pengetahuan siswa itu berlaku untuk menghadapi persoalan baru yang berkaitan. Guru membantu mengevaluasi hipotesis dan kesimpulan siswa (Yamin, 2008: 17).

Guru/dosen yang konstruktivis tidak akan pernah membenarkan ajarannya dengan mengklaim bahwa" ini satu-satunya yang benar". "Ini adalah jalan yang terbaik". Atau ini adalah jalan yang terefektif untuk masalah ini".

Pendidik perlu menciptakan suasana yang membuat siswa/ mahasiswa antusias terhadap persoalan yang ada sehingga mereka mau mencoba memecahkan persoalannya.

Guru perlu membantu mengaktifkan siswa untuk berfikir. Guru boleh memberi informasi arahan tetapi tidak boleh memaksakan.

Selanjutnya guru yang konstruktif pula menurut Julyan dan Duckworth bahwa: pertama: guru harus benarbenar mendengar dengan sungguh interprestasi siswa terhadap data yang ditemukan sambil menaruh perhatian khusus kepada keraguan,kesulitan dan kebingungan siswa. Kedua: Guru perlu memperhatikan perbedaan pendapat dalam kelas, memberi penghargaan kepada siswa Ketiga: guru harus mengerti bahwa ketidakmengertian siswa merupakan langkah awal untuk memulai pelajaran (Yamin, 2008: 1920).

Dari uraian di atas, kita menyadari bahwa tugas dan kewajiban guru tidaklah sederhana dan mudah. Belajar sebagai proses mengkonstruksi pengetahuan oleh siswa harus ditindak lanjuti oleh guru dengan berperan membantu mereka dalam mengkonstruksi pengetahuan tersebut. Proses mengkonstruksi tersebut membuat mereka aktif, kreatif dan tidak sekedar menerima, mencatat, bahkan menghafal yang selama ini dilakukan. Kini, belajar menjadi proses berfikir, mengamati, membandingkan, bahkan menganalis pengalaman dimana guru berperan sebagai pembimbingnya.

Sehubungan dengan tugas dan peran guru di atas, maka sebagai seorang guru tidak saja menyampaikan ilmu pengetahuan kepada siswa/ mahasiswa, tetapi menggerakkan siswa untuk menggunakan apa yang mereka miliki berupa pengetahuan, pengalaman, agar dapat memahami dan menginterpretasikan pengetahuan dan pengalaman belajar mereka. Dalam proses pembelajaran, pendidik harus mampu mengajukan masalah-masalah dunia nyata dalam proses belajar. Dalam dunia nyata masalahnya kompleks dan multifaset. Penelaahan masalah harus dilaksanakan dengan interdisipliner. Hal ini sesuai dengan cara kerja otak yang selalu mencari pola dan hubungan antara ide-ide dan konsep konsep. Kerangka-kerangka konsep ini disebut skemata dan merupakan file pengetahuan.

\section{SIMPULAN}

Setelah menjelaskan kedua teori tersebut baik dari segi konsep belajar, strategi pembelajaran dan peran guru menurut kedua teori di atas, sebagai langkah selanjutnya adalah memperbandingkannya. Perbandingan tersebut dapat dilihat pada tabel berikut: 
Tabel 1

Perbandingan Teori Belajar Behaviorisme dan Konstructivisme

\begin{tabular}{|c|c|c|}
\hline Aspek & Teori behaviorisme & Teori Konstruktivisme \\
\hline Belajar & $\begin{array}{l}\text { - } \text { Belajar adalah perubahan perilaku } \\
\text { - Perilaku tersebut harus selalu tampak } \\
\text { - Perilaku harus dapat diukur } \\
\text { - Mengakui pentingnya masukan atau } \\
\text { input yang berupa stimulus dan } \\
\text { keluaran atau output yang berupa } \\
\text { respon } \\
\text { - Pembiasaan dan latihan menjadi } \\
\text { esensial dalam belajar } \\
\text { - Apa yang terjadi antara stimulus dan } \\
\text { respon dianggap tidak penting } \\
\text { diperhatikan karena tidak dapat } \\
\text { diamati. } \\
\text { - Kegagalan atau ketidakmampuan dalam } \\
\text { penambahan pengetahuan } \\
\text { dikatagorikan sebagai kegagalan yang } \\
\text { perlu dihukum } \\
\text { Mementingkan } \\
\text { reinforcement }\end{array}$ & $\begin{array}{l}\text { - Siswa membangun } \\
\text { pemahamannya } \\
\text { sendiri dari hasil } \\
\text { mereka belajar bukan } \\
\text { karena disampaikan } \\
\text { pada mereka. } \\
\text { - Pelajaran baru sangat } \\
\text { tergantung dengan } \\
\text { pelajaran sebelumnya } \\
\text { - Belajar dapat } \\
\text { ditingkatkan dengan } \\
\text { interaksi sosial } \\
\text { - Penugasan- } \\
\text { penugasan dalam } \\
\text { belajar dapat } \\
\text { meningkatkan } \\
\text { kebermaknaan proses } \\
\text { pembelajaran. } \\
\text { - Siswa membangun } \\
\text { interpretasi personal } \\
\text { terhadap dunia luar } \\
\text { berdasarkan } \\
\text { pengalaman } \\
\text { individual } \\
\text { interaksi. }\end{array}$ \\
\hline $\begin{array}{l}\text { Metode } \\
\text { atau } \\
\text { strategi }\end{array}$ & $\begin{array}{l}\text { - } \text { Membiasakan perilaku yang dikondisikan } \\
\text { - Mengulang-ulang sehingga menjadi } \\
\text { kebiasaan } \\
\text { - } \text { Trial and Error }\end{array}$ & $\begin{array}{l}\text {-Menggunakan berbagai } \\
\text { strategi pembelajaran } \\
\text { aktiv. }\end{array}$ \\
\hline $\begin{array}{l}\text { Peran } \\
\text { Guru }\end{array}$ & $\begin{array}{l}\text { - Sosok yang menentukan dimana isyarat } \\
\text { dapat memancing respon siswa. } \\
\text { - Pengajar, yaitu menyampaikan berbagai } \\
\text { stimulus. } \\
\text { - Pengatur, yaitu mengatur promting } \\
\text { (bimbingan) untuk dipasangkan dengan } \\
\text { stimulus. } \\
\text { - Pengatur kondisi lingkungan sehingga } \\
\text { siswa dapat merespon dengan benar dan } \\
\text { siswa dapat menerima reinfoecement. } \\
\text { - Model yang selalu mencontohkan perilaku } \\
\text { kepada siswa } \\
\text {-Pemberi instruksi singkat yang diikuti } \\
\text { contoh-contoh baik dilakukan sendiri } \\
\text { maupun melalui simulasi. }\end{array}$ & $\begin{array}{l}\text { - guru atau dosen } \\
\text { berperan sebagai } \\
\text { mediator dan fasilitator } \\
\text { - Guru memonitor dan } \\
\text { selalu memperbaharui } \\
\text { pengalaman siswa }\end{array}$ \\
\hline
\end{tabular}




\begin{abstract}
Setelah memperbandingkan ketiga topic di atas perspektif Behaviorisme dan Konstruktivisme dapat disimpulkan bahwa dari aspek konsep belajar teori Konstruktiv lebih menekankan proses belajar dari pada hasil belajar sebagaimana halnya pendapat Behavirisme. Proses belajar yang ditekankan oleh Konstruktivisme lebih member peluang kepada peserta didik untuk melakukan kegiatan belajar dengan strategi yang berpusat pada peserta didik dari pada guru. Oleh karena itu peran siswa lebih dominan dalam Konstruktif.

Dalam pembelajaran kedua teori ini dapat bekerja sama yang mana Behaviorisme berperan di dalam mengkondisikan belajar sedangkan proses dan hasil dapat menggunakan Behaviorisme. Peran guru adalah mengkondisikan belajar dengan menggunakan berbagai strategi yang berpusat pada peserta didik.
\end{abstract}

\section{DAFTAR RUJUKAN}

Budiningsih, Asri. 2005. Teori Belajar Dan Pembelajaran. Jakarta: Rineka Cipta.

Kauchak, Donal P. dan Eggen, Paul D., 1998. Learning and Teaching, Research Based Methods. Boston: Allyn And Bacon.
Rohman, Arif. 2013. Pendidikan Komparatif. Yogyakarta: Aswaja Pressindo.

Sanjaya, Wina. 2010. Strategi Pembelajaran. Jakarta: Prenada Media Group. . 2005. Pembelajaran Dalam Implementasi KBK. Jakarta: Prenada Media.

Shaleh, Abdurrahman dan Wahab, Muhbib Abdul. 2004. Psikologi Perspektif Islam. Jakarta: Kencana.

Slameto. 1991. Belajar Dan FaktorFaktor Yang Mempengaruhinya. Jakarta: Rineka Cipta.

Surya, M., 1997. Psikologi Pembelajaran dan Pengajaran. Bandung: IKIP Bandung.

Syah, Muhibbin. 2004. Psikologi Pendidikan dengan Pendekatan Baru. Bandung: Remaja Rosda Karya.

Yamin, Martinis. 2008. Paradigma Pendidikan Konstruktivim. Jakarta: GP Press.

Winfred. F. Hill, Teories OF Learning, Diterjemahkan oleh M. Kozim, Bandung: Penerbit Nusa Media, 2010, cetakan IV.

Zaini, Hisyam et. al., 2010. Strategi Pembelajaran Aktif. Jogjakarta: CTSD. 